\title{
新生児期に必要なカテーテル治療
}

\author{
北野 正尚 \\ 国立循環器病研究センター小児循環器科
}

\section{Essential Catheter Interventions in Neonatal Period}

\author{
Masataka Kitano \\ Department of Pediatric Cardiology, National Cerebral and Cardiovascular Center, Japan
}

\begin{abstract}
Development of low-profile materials has enabled various catheter interventions to be performed in the neonatal period. In this study, three clinically important issues related to neonatal catheter interventions are discussed: 1) alternative methods when balloon atrial septostomy is difficult to perform; 2) balloon pulmonary valvuloplasty in neonates with pulmonary atresia with intact ventricular septum, and the long-term outcomes of the procedure; and 3) the safe technique of ductal stenting in patients with hypoplastic left heart syndrome. Although neonatal catheter interventions are less invasive than surgical procedures, there are several severe complications. Therefore, it is important that these procedures are performed with sufficient information and understanding of the potential complications and ways to deal with them.
\end{abstract}

ロープロファイルな治療器具が開発されたことで, 新生児においても様々なカテーテル治療が施行さ れるようになった. 本稿では, 1. 通常の心房中隔裂開術が困難な場合のその方法, 2. 長期経過から再 検討した心室中隔欠損を伴わない肺動脈閉鎖に対するカテーテル的弁形成術, 3. 左心低形成症候群に おける安全な動脈管ステント留置術の 3 項目に関して, 臨床の場で役立つように解説した。 新生児の カテーテル治療は外科治療よりも低侵襲で遂行できるが, 重篤な合併症が起こりえるので, その合併 症と対応策を熟知してから治療に臨む必要がある.

Keywords: balloon atrial septostomy, balloon pulmonary valvuloplasty, ductal stenting, complications, neonates

\section{はじめに}

近年様々なロープロファイルな治療器具が開発・使 用可能になり, 新生児期においても様々なカテーテル 治療が施行されるようになった。 その詳細を Table 1 に示す。本稿では第 11 回教育セミナーで講義した内 容, 即ち新生児期に施行されているカテーテル治療の 内の主要な 3 手技に関して解説する.

\section{Balloon Atrial Septostomy (BAS): 心房中隔裂開術 ${ }^{1)}$}

BAS の手技（Fig. $1^{*}$ )

房室弁の損傷をきたす可能性があるので必ず正面・ 側面透視を使用する．右房（RA）内にあるカテーテ ルを後左方へ向けて左房（LA）へ通す．軽くテスト インフレーションして心室に引き込まれないことを確 認してから, 力まずにスピードを付けてシャフトを 手前に短く引く(B)，抵抗を感じるが直ぐに下大静脈 （IVC）へ入り込むので(C)，RAへ押し戻す(D). 小 さめ（1 cc の注入）から開始し，徐々にサイズアップ 


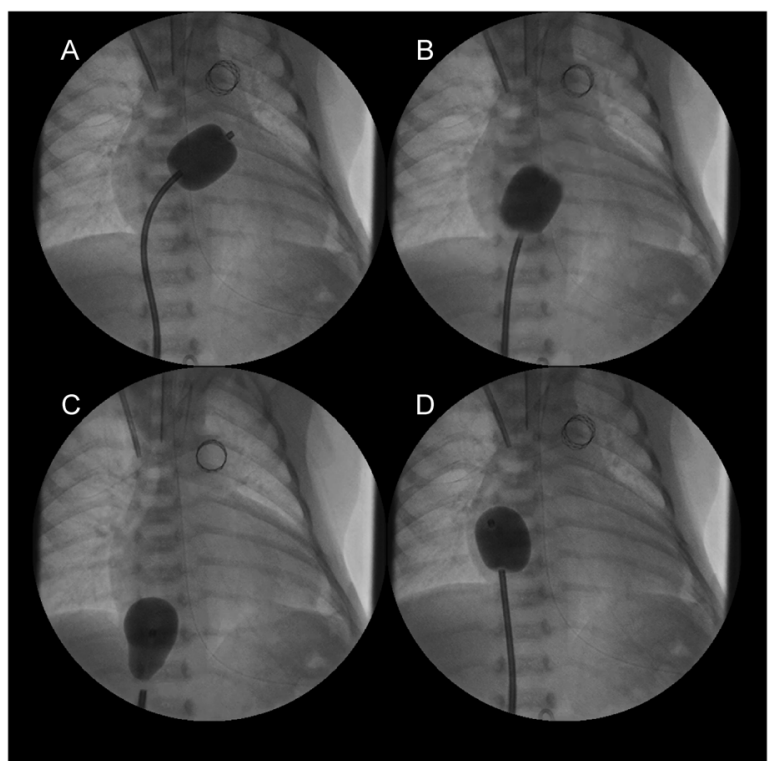

Fig. 1 Serial fluoroscopic images during BAS

Table 1 Catheter interventions performed neonatal period

1. Opening of Atrial Communications

- Atrial Septostomy

- Transseptal Technique

2. Transcatheter Balloon Dilation of Cardiac Valves

- Pulmonary Valvuloplasty

- Aortic Valvuloplasty

3. Transcatheter Balloon Angioplasty or Stent Implantation

- Native Coarctation and Recoarctation Angioplasty

- Pulmonary Artery Angioplasty and Stent Implantation

- Pulmonary Vein Stenting

- Vertical Vein Stenting

- Ductal Stenting

4. Transcatheter Vascular Occlusion

- Patent Ductus Arteriosus

- Aortopulmonary Collateral Vessels

5. Hybrid Procedures

- Ductal Stenting with Bilateral Pulmonary Artery Banding in HLHS and Complex Single-Ventricle Physiology

Note: Common procedures are indicated in bold type.

するのが安全である.

現在日本でBAS に保険適応されているカテーテ ルは 2 種類ある. Rashkind catheter は最大注入量が $2 \mathrm{cc}$, 最大径が $14 \mathrm{~mm}$, 適合シースは $6 \mathrm{~F}$ である. 一方 Miller catheter は最大注入量が $4 \mathrm{cc}$, 最大径が $19 \mathrm{~mm}$ と大きいが, 適合シースは $7 \mathrm{~F}$ である. できる限り大 腿静脈（FV）の閉塞を避けるために Rashkind catheter が選択されることが多い．低体重児の場合はさら に FV が細いので, BAS には保険適応がないが，4F， 5F のシースで使用できる血栓除去用の Fogaty cath-
Table 2 Catheters used for BAS in Japan

\begin{tabular}{llcc}
\hline Catheter & $\begin{array}{c}\text { Maximum } \\
\text { infusion } \\
\text { volume }\end{array}$ & $\begin{array}{c}\text { Maximum } \\
\text { balloon } \\
\text { diameter }\end{array}$ & $\begin{array}{c}\text { Appropreate } \\
\text { sheath size }\end{array}$ \\
\hline Miller & $4 \mathrm{cc}$ & $19 \mathrm{~mm}$ & $7 \mathrm{~F}$ \\
\hline Rashkind & $2 \mathrm{cc}$ & $14 \mathrm{~mm}$ & $6 \mathrm{~F}$ \\
\hline Fogaty & $1.5 \mathrm{cc}$ & $11 \mathrm{~mm}$ & $5 \mathrm{~F}$ \\
& $0.75 \mathrm{cc}$ & $9 \mathrm{~mm}$ & $4 \mathrm{~F}$ \\
\hline
\end{tabular}

eter が有用である（Table 2)。新生児期に BAS が必 要となる疾患としては, 心房間 mixing が必要な完全 大血管転位（TGA）・両大血管右室起始（DORV）, 生存に心房間左右短絡が必要な左心低形成症候群 (HLHS) - 重症大動脈弁狭窄（cAS）, 反対に右左短絡 が必要な三尖弁閉鎖（TA）・心室中隔欠損を伴わない 肺動脈閉鎖（PA IVS）などがある.

通常の BAS が困難, 危険, 無効な状況としては, 肥厚した心房中隔壁, intact atrial septum (IAS), 小さい LA，低体重児，両側 FV の閉塞・IVC 離断な ぞがある. 肥厚した心房中隔壁に対して以前は blade atrial septostomy が施行されたが，心房壁や右室流出 路（RVOT）の裂傷から死亡する合併症があり, 近 年はあまり施行されなくなっている ${ }^{2,3)}$. これに対し て balloon atrial septal dilation は効果がやや劣るが安 全に施行できる．有効な欠損孔を得るためには新生 児でも $10 \sim 12 \mathrm{~mm}$ 径のバルーンが必要である ${ }^{4,5)}$. inflation/deflation が素早くできる Armada（12 mm× $20 \mathrm{~mm}$; Abot）などが適している. 当院での経験にな るが, Balloon atrial septal dilationにBASを組み合 わせることで十分な効果が得られている. IAS に対し て日本では昨年まで Brockenbrough needle を使用せ ざるを得なかった．新生児・乳児の体格でも心房中隔 穿孔は不可能ではないが，特に HLHS では心房中隔 壁が厚く，それを穿孔するだけの LA 容積（奥行き） がない場合が多く（Fig. 2), 心房壁の穿孔・心タン ポナーデの合併率が高くなる ${ }^{6,7)}$. 欧米では 10 数年 前から radiofrequency wire を用いた心房中隔穿孔が 施行されている $(\text { Fig. 3 })^{8)}$ 。 心房中隔に接触させて通 電するだけで中隔を穿孔できるので，LA が小さい新 生児の肥厚した IAS でもより安全に穿孔できる. 日 本でも 2014 年 8 月から Nykanen RF wire が使用可能 となった (Fig. 4).この wireの直径は 0.024", 長さ は $265 \mathrm{~cm}$ で, 先端の Active atraumatic tip の直径は 0.016 , 長さは $1.5 \mathrm{~mm}$ である. Active tip 以外の部分 は整形が可能である. Connector cable で Generator と接続し，5１0W，1〜10 secの通電で組織の穿通が 


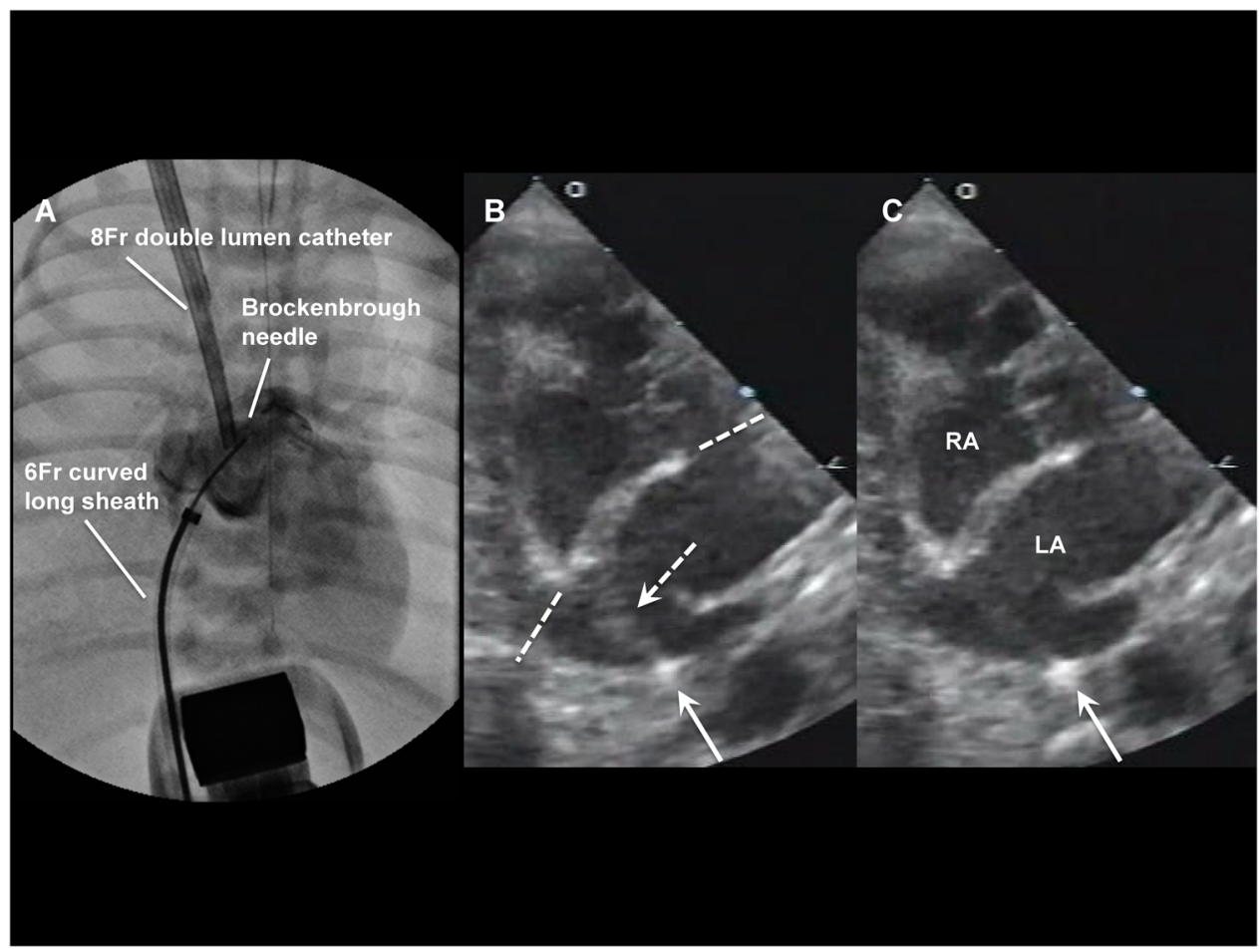

Fig. 2 Transseptal puncture using a Brockenbrough needle on venovenous, extracorporeal membrane oxygenation in a neonate with severe mitral stenosis, intact atrial septum, and double outlet right ventricle

Photograph A shows the left atrial angiogram after transseptal puncture. On transthoracic echocardiogram, immediately before the needle entered the septum, the thick atrial septum (between broken lines) was elongated (broken arrow) and the tip of the needle (arrow) was almost in contact with the left atrial posterior wall (B). Immediately after passing the septum, the tip barely escaped passing through the posterior wall (C; arrow). RA, right atrium; LA, left atrium.



Fig. 3 Transseptal perforation with a radiofrequency wire $(A)$ and subsequent balloon atrial septal dilation (B) TEE, transesophageal echocardiography; ICE, intra-cardiac echocardiography. 
Table 3 Complications related to BAS in reicent years in Japan

\begin{tabular}{|c|c|}
\hline Year & Complications (number) \\
\hline 2011 & Atrial fibrillation (1), hypotesion-death (Balloon dilation) (1) \\
\hline 2010 & $\begin{array}{l}\text { Left atrium perforation-death (1), cerebral infarction (1), stent migration-surgery (1), } \\
\text { retroperitonear bleeding (1), atrioventricular block (1) }\end{array}$ \\
\hline 2009 & $\begin{array}{l}\text { Supraventricular tachycardia (1), pericardial effusion (2) - (Brockenbrough) (1), cardiac } \\
\text { tamponade (Brockenbrough) (1) }\end{array}$ \\
\hline 2008 & $\begin{array}{l}\text { Tricuspid regurgitation (1), bleeding (1), stent migration-surgery (1), internal iliac artery oc- } \\
\text { clusion due to embolization of ruptured-balloon fragment (1) }\end{array}$ \\
\hline 2007 & Atrial fibrillation (1), atrial flutter (1) \\
\hline 2006 & Mitral regurgitation (1), tricuspid regurgitation (1), cardiac tamponade (Brockenbrough) (1) \\
\hline 2005 & Atrial fibrillation (1), pericardial effusion (1) \\
\hline
\end{tabular}

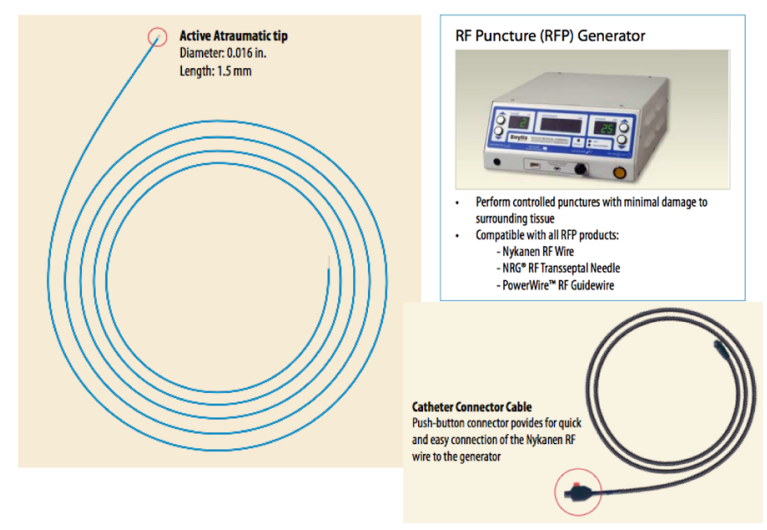

Fig. 4 Nykanen RF wire

Wire: outer diameter $0.024 "$, length $265 \mathrm{~cm}$; Active tip: diameter $0.016^{\prime \prime}$, length $1.5 \mathrm{~mm}$.

可能である．現在日本では PA IVS の肺動脈弁穿孔と IAS の心房中隔穿孔に適応があり，その使用には講習 が必要である．肥厚した心房中隔のために BAS が無 効の場合には stent septostomy も有効である. 留置後 抗血小板薬だけでは血栓形成の報告があることから 抗凝固療法が必要と思われる ${ }^{9)}$. また stent migration の報告や強度の内膜増殖を来す期間が不明であり, 注 意を要する ${ }^{10)}$.

\section{BAS の合併症}

バルーンの破裂, 破裂バルーン片による塞栓, バ ルーンデフレーション困難, IVC 閉塞・損傷, 三尖 弁 (TV)・僧帽弁 (MV) 損傷, 心房壁裂傷, 肺静脈 裂傷，高度房室ブロック・徐脈，出血などがあるが， 合併症を熟知して臨むことでその多くは回避できる. 近年日本で発生した BAS に関連した合併症を Table 3 に示す. Brockenbrough 法による心タンポナーデが 多いこと，近年でも心房壁等の穿孔・裂傷から死亡す る症例があることを銘記すべきである.

\section{2. 新生児 PA IVS に対するバルーン肺動脈弁 形成術 : Balloon Pulmonary Valvuloplasty (BPV)}

\section{要点}

・治療対象を厳密にすれば，右室（RV）の発育が期 待できる

・カテーテル治療中最も難易度が高い手技の 1 つであ り，重篤な合併症が起こりえる

・術後の管理は特殊であり，重要である

・RV が発育した場合の二心室循環は良好であるが, 遠隔期の問題もある

PA IVS は RV の容積と形態から 3 群に分類される (Figs. 5, 6). この分類は BPV の適応判断と治療後の 経過の予測に有用である ${ }^{11)}$ ，正確な RV 容積は造影 検査などをしないと計測できないが，TV 弁輪径は $R V$ 容積と相関するので，エコー検査でもある程度の 適応判定が可能である。

\section{手技 (Fig. 7)}

0. 安全に治療を遂行するために Prostagrandin E1 （PGE1）の持続静注を継続するだけでなく, 鎮静・ 筋弛緩薬を使用し，人工呼吸管理下に施行する.

1. RV 造影を行い, RV の形態と容積および Sinusoidal communication の有無を確認する (A, B).

2. 左室（LV）または大動脈（Ao）造影を行い, 肺 動脈弁（PV）の位置を確認し，弁輪径を計測する (C).

3. JR 型のガイディングカテーテル (Optiflush XL 4F JR japan special など）を慎重に PV 直下まで進め る(D).

4. ガイディングカテーテルの中へマイクロカテーテ ル $(1.8 \mathrm{~F}$ FineCrossなど) を進め，その中に先端 を $45^{\circ}$ 程度屈曲させた硬めの 0.014 ”コロナリー用ガ 


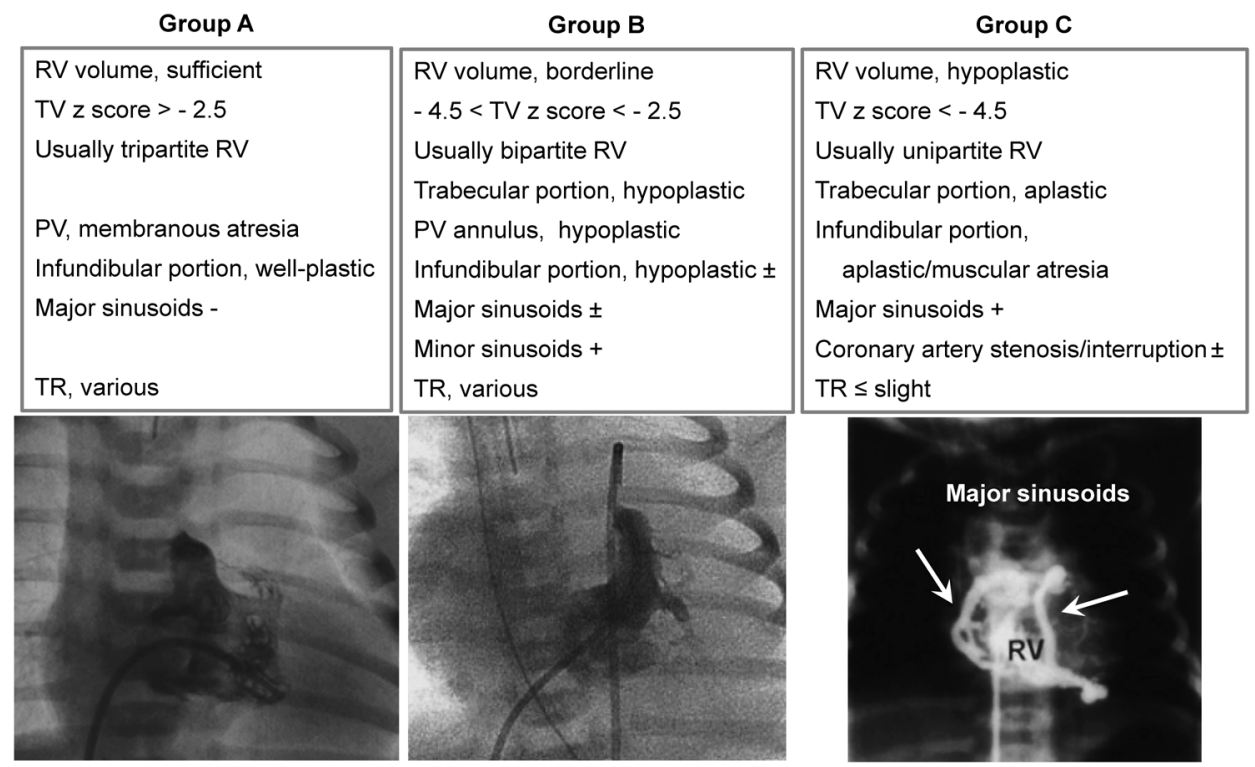

Fig. 5 Categorization of neonates with pulmonary atresia with intact ventricular septum according to their right ventricular volume and morphology

$\mathrm{RV}$, right ventricle; TV, tricuspid valve; PV, pulmonary valve; TR, tricuspid regurgitation.

\begin{tabular}{|c|c|c|}
\hline Group A & Group B & Group C \\
\hline \multirow[t]{3}{*}{$\begin{array}{l}\text { - RV can grow after BPV. } \\
\text { - Biventricular circulation } \\
\text { will be accomplished. }\end{array}$} & \multirow{3}{*}{$\begin{array}{l}\text { - BPV may be performed in case without } \\
\text { RV dependent coronary circulation. } \\
\text { - High possibility of BT shunt or DS } \\
\text { - If the RV grows, } \\
\text { biventricular circulation will be achieved. } \\
\text { - If the RV does not grow, } \\
\text { one and a half ventricular repair } \\
\text { or Fontan operation will be selected. }\end{array}$} & \multirow{2}{*}{$\begin{array}{l}\text { - Usually, BPV is not performed in case } \\
\text { with RV dependent coronary circulation. } \\
\text { - Fontan candidate } \\
\text { - First palliation is BT shunt or DS } \pm \text { BAS. }\end{array}$} \\
\hline & & \\
\hline & & \\
\hline
\end{tabular}

Fig. 6 Predicted clinical course after balloon pulmonary valvuloplasty (BPV) in each group $\mathrm{RV}$, right ventricle; BT, Blalock-Taussig; DS, ductal stenting; BAS, balloon atrial septostomy.

イドワイヤー（Grand Slam など）の stiff side を進 める. JR 型カテーテルは PV下の上方に位置する ことが多いので $(\mathrm{E})$, 弁穿通後上方ではなく後方へ 向かう様にガイドワイヤーを整形し，RVOT の穿 孔を回避する $(\mathrm{F})$. 正面・側面造影でガイディング カテーテルが PV に接していることを確実に把握 してからガイドワイヤーを押して PV を穿孔する. その時通常は軽い抵抗を感じる.

5. 弁穿孔成功後, ガイドワイヤーを肺動脈分岐部ま で進めて $(\mathrm{G})$ ，これに追従させてマイクロカテーテ ルを肺動脈末梢まで進める $(\mathrm{H})$. あるいはガイド ワイヤーをより柔らかい Radifocus などに交換し て，それを肺動脈末梢まで進めて，マイクロカテー テルを追従させる．続いてコロナリー用ガイドワ イヤーの soft side をできる限り肺動脈末梢まで進 めて留置する.

6. $\phi 2 \mathrm{~mm}$ 程度の coronary balloon catheter $\mathrm{PV}$ 上
まで追従させて, pre-dilation を施行する．Balloon catheter が弁を通過しない場合は，弁下まで Long sheath を運び，カテーテルがたわまないようにす ると通過できる(I).

7. 続いて PV 弁輪径の 120 125\%の径の balloon catheter で BPV を行う（J, K）。過大な balloonを 選択すると将来重度の肺動脈弁閉鎖不全（PR）が 生じる原因となるので注意する.

8. BPV に成功すると順行性血流が増加して $\mathrm{SpO}_{2}$ は 上昇する．この時点では肺高血圧が残存している ので， RV 圧が LV 圧以下であればよい， RV 造影 を行い, 肺動脈弁下狭窄の程度を確認する(L). 弁 下狭窄がなくかつ RV 圧が LV 圧を越えている場合 は $1 \mathrm{~mm}$ サイズアップした径の balloon で re-BPV を施行する. 


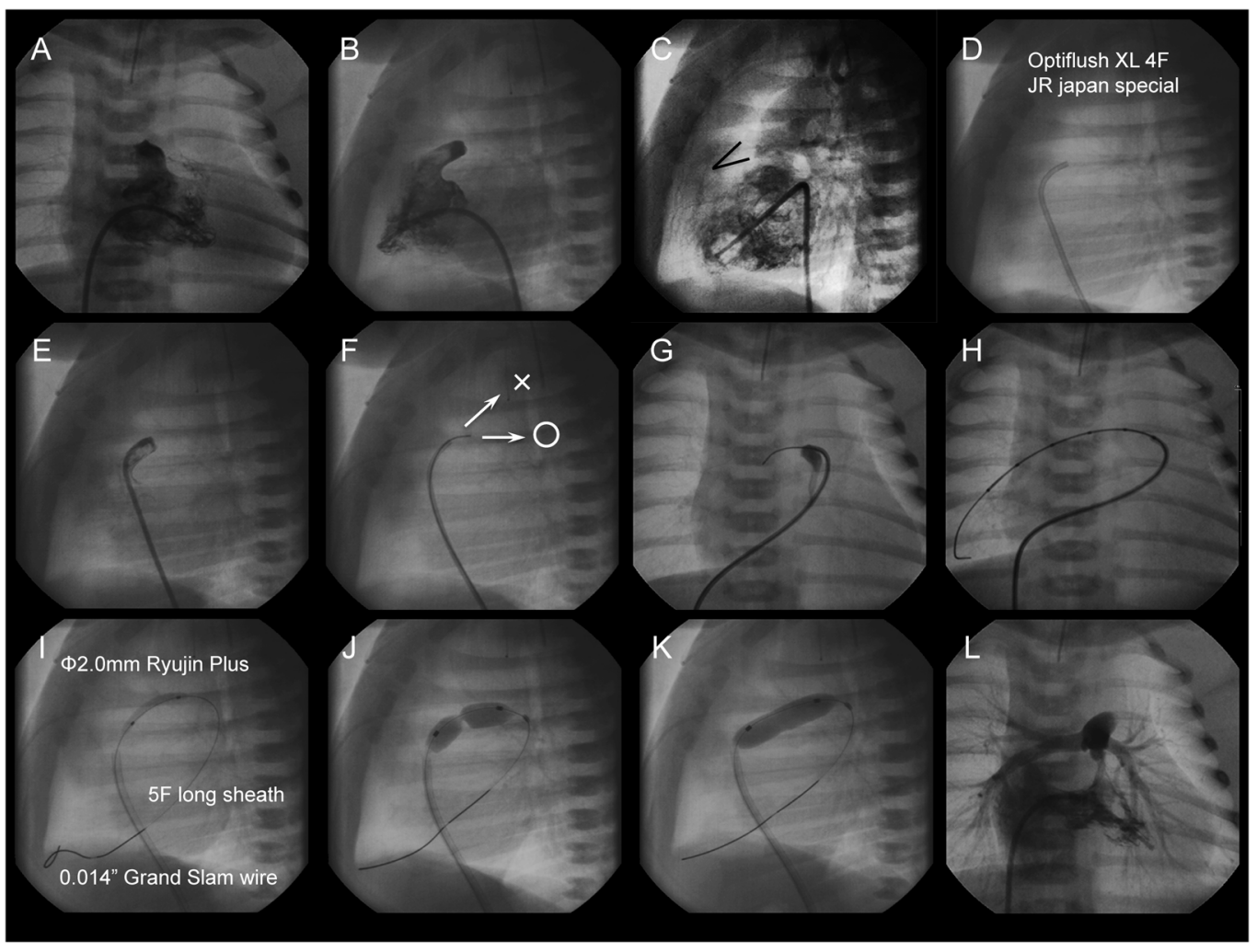

Fig. 7 Balloon pulmonary valvuloplasty in a neonate with pulmonary atresia with intact ventricular septum

Table 414 patients' charactaristics at balloon pulmonary valvuloplasty

\begin{tabular}{|c|c|c|c|}
\hline & Range & Median & \\
\hline Age & $1-21$ & 7 & [day] \\
\hline Weight & $2.4-3.6$ & 3.2 & {$[\mathrm{~kg}]$} \\
\hline Tricuspid valve annulus & $6.1-16.5$ & 10 & {$[\mathrm{~mm}]$} \\
\hline z-value & $-5.6-3.4$ & -1.5 & \\
\hline Right ventricle (RV) end-diastolic volume & $2.6-10.6$ & 5.2 & {$[\mathrm{~mL}]$} \\
\hline$\%$ of normal & $36-161$ & 63 & \\
\hline Pulmonary valve (PV) annulus & $4-8.1$ & 5.9 & {$[\mathrm{~mm}]$} \\
\hline z-value & $-5.8-0.7$ & -1.9 & \\
\hline Balloon diameter/PV diameter & $0.67-1.3$ & 1.12 & \\
\hline
\end{tabular}

Note: All patients have tripartite RV and no sinusoidal communication.

\section{BPV 後の管理}

RV は減圧されても拡張能の改善に 1 2 週間要す るので，1 週間程度 PGE1 で動脈管（AD）を開存さ せ，酸素は使用せずに十分な鎮静と人工呼吸管理を継 続する. エコーで TV の流入および RV から肺動脈へ の順行性血流の増加が十分であれば PGE1 を中止し てみる. $\mathrm{AD}$ が収縮しても $\mathrm{SpO}_{2}$ が $70 \%$ 以上に維持さ れれば，酸素を使用して，人工呼吸から離脱する。そ の後 $\mathrm{RV}$ は徐々に発育し, $\mathrm{SpO}_{2}$ は上昇する. $\mathrm{AD}$ が 収縮すると $\mathrm{SpO}_{2}$ が $70 \%$ 以上に維持されない場合は PGE1 を再開し, さらに 1 週間 RV の拡張能が改善す
るのを待ってから PGE1 を中止してみる.この時点 で $\mathrm{SpO}_{2}$ が維持できない場合は, Blalock-Taussig (BT) shunt か ductal stenting（DS）が必要である.

\section{遠隔期成績から新生児期の治療方針を考える}

当院で 1995 年 10 月から 2008 年 11 月の間に新生 児PA IVS 14 症例に対して施行したBPVの遠隔成 績から新生児期の治療方針を再検討した。 14 症例と も RV 構造 は tripartite で sinusoidal communication はない. 14 症例の BPV 時の詳細をTable 4 に示 す. BPV 後の経過は Fig. 8 にあるように 13 症例で 


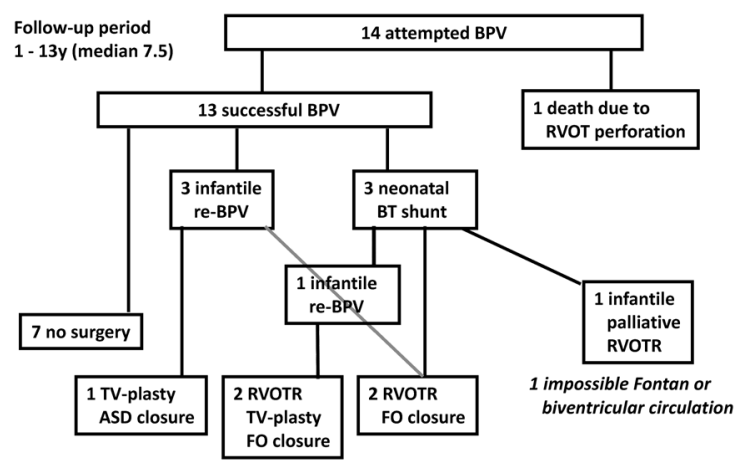

11 Biventricular circulation

Fig. 8 The outcome of 14 neonates with PA IVS after BPV at National Cerebral and Cardiovascular Center, Japan

PA IVS, pulmonary atresia with intact ventricular septum; BPV, balloon pulmonary valvuloplasty; RVOT, right ventricle outflow; RVOTR, right ventricular outflow reconstruction; TV, tricuspid valve; ASD, atrial septal defect; FO, foramen ovale.

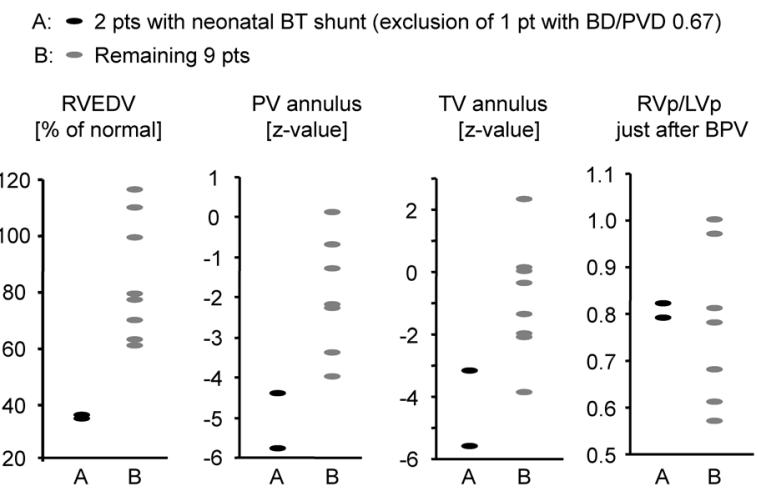

Fig. 9 Comparison between the two groups with and without neonatal BT shunt after successful BPV

BT, Blalock-Taussig; BPV, balloon pulmonary valvuloplasty; BD, balloon diameter; PVD pulmonary valve annulus diameter; RVEDV, right ventricular end-diastolic volume; RVp, right ventricular systolic pressure; LVp left ventricular systolic pressure.

手技に成功し, その内の 7 症例は外科治療が不要で あったが，残りの 6 症例は経過中に新生児期の BT shunt または遠隔期の右室流出路形成（RVOTR）や TV-plasty などの外科治療介入が必要であった。最終 的に 11 症例に二心室循環が成立している. Fig. 9 に 示すように右室拡張末期容積（RVEDV）が 40\%未満 では BPV に成功しても肺血流量が不十分なために新 生児期に BT shunt が必要であった. Fig. 10 に示すよ うにBPV 後 RV は徐々に発育する。 RVEDV が $40 \%$ 未満であるものが 2 症例あった。 その内の TV 弁輪

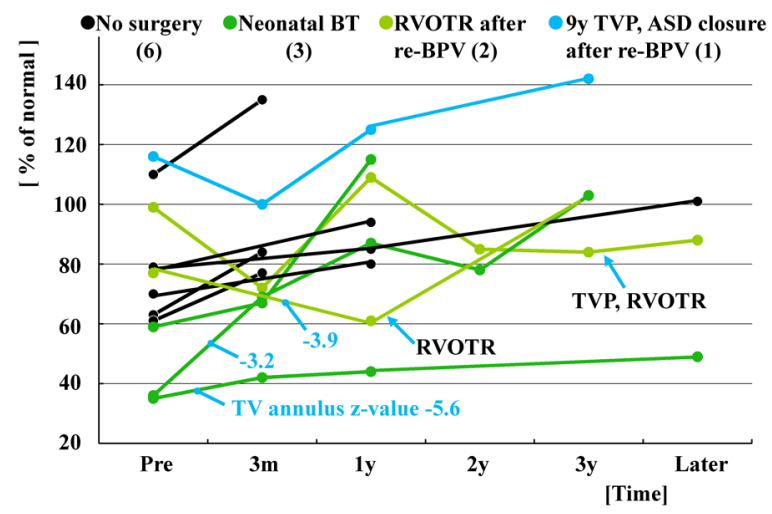

Fig. 10 Change in the right ventricular end-diastolic volume after BPV

BPV, balloon pulmonary valvuloplasty; RVOTR, right ventricular outflow reconstruction; TVP, tricuspid valvuloplasty; ASD, atrial septal defect.

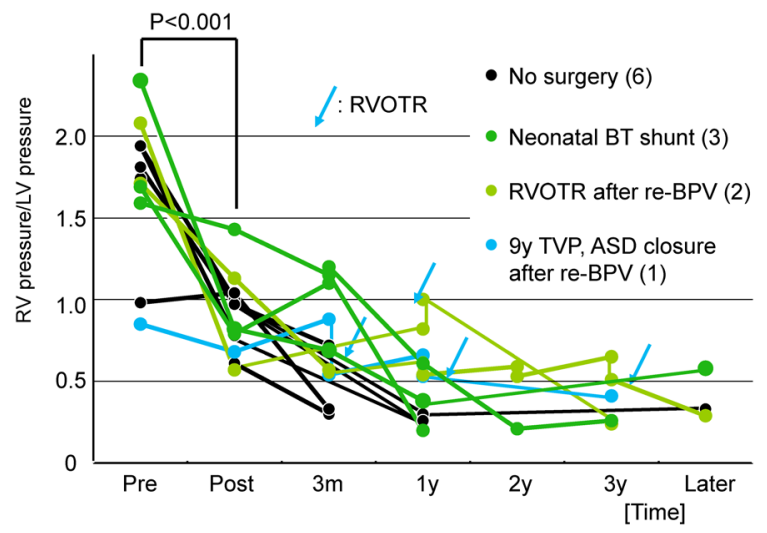

Fig. 11 Change in the ratio of RV pressure/LV pressure after BPV

BPV, balloon pulmonary valvuloplasty; RV, right ventricle; LV left ventricle; BT, Blalock-Taussig; RVOTR, right ventricular outflow reconstruction; TVP, tricuspid valvuloplasty; ASD, atrial septal defect.

径の $\mathrm{z}$-value がー4 以上のものは BT shunt 施行後の経 過中に RV が発育した。しかし TV 弁輪径の $\mathrm{z}$-value がー4末満のものは RV を通過する血流量が増加し ないので, RV が発育せず, 結局二心室循環が成立 しなかった。一方 RV 圧は経過中徐々に低下してゆ く（Fig. 11）. Fig. 12 に示すように, 遠隔期に肺動脈 弁狭窄（PS）の程度は徐々に軽減してゆくのに対し て，PRは徐々に増加してゆく．Fig. 13 に示すように PS と PR が相反関係にあることから最終目標は PS, PR ともに軽度な状態である。 そのためにも新生児期 の BPV で使用する balloon のサイズは可能な限り PV 弁輪径の 120 ～125\% 程度に留めるべきである．また PR に伴って三尖弁閉鎖不全（TR）が増悪する傾向が 


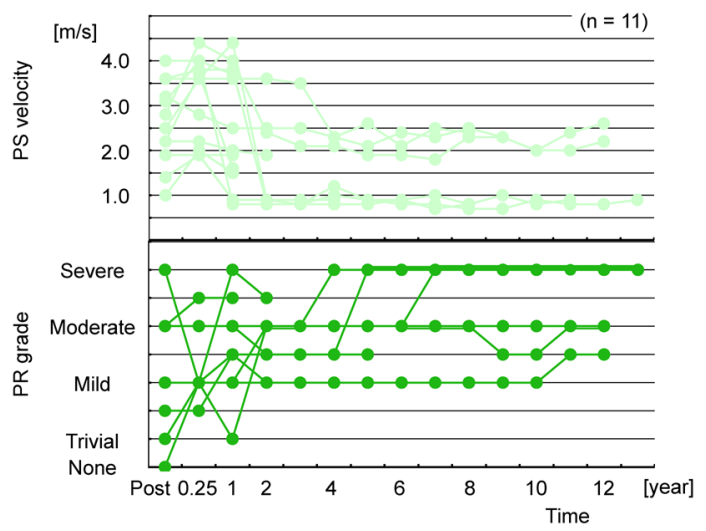

Fig. 12 Change in pulmonary stenosis (PS) velocity and grade of pulmonary regurgitation (PR) using transthoracic echocardiography

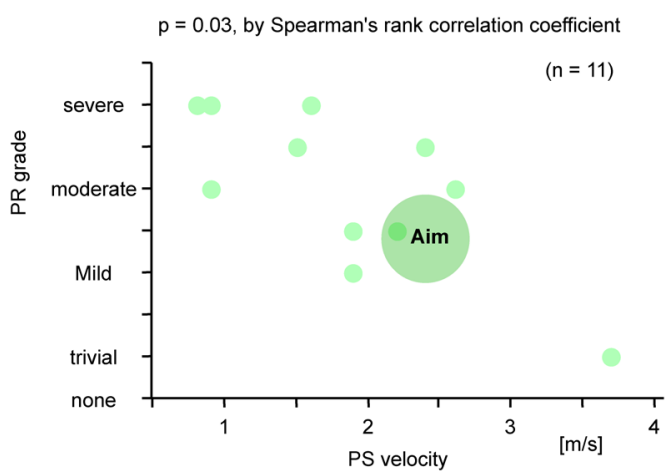

Fig. 13 The most recent relationship between pulmonary stenosis (PS) velocity and grade of pulmonary regurgitation (PR) using transthoracic echocardiography at the latest time

あり，形態的に弁形成が可能であれば形成術を考慮す る.これら 11 症例の最近の状態は心室性期外収縮以 外に問題となる不整脈はなく, 運動制限も疲労を感じ たら休憩する程度と比較的 QOL は高い。

結論として適応を厳密にすれば, 即ち tripartite RV, sinusiodal communication なし, TV annulus z-score> $-4, \mathrm{RVEDV} \geq 60 \%$ of normal, PV annulus $\mathrm{z}$-score $\geq$ -4 を満たす場合に新生児期に施行する BPV の予後は 良好と判断される。

\section{Ductal Stenting (DS): 動脈管ステント留置術}

新生児期にDS が施行される場合がある疾患とし て HSHS, cAS; 大動脈弓離断 (IAA), 大動脈縮窄 (CoA); PA IVS, 重症肺動脈弁狭窄 (cPS); ファロー

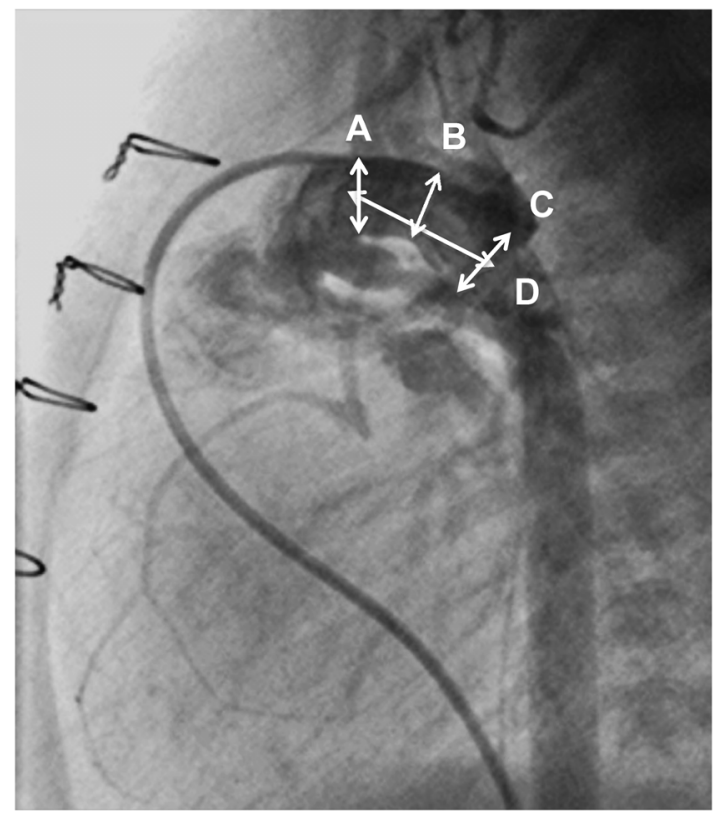

Fig. 14 Measurement of the diameters (arrow A, PA side; arrow $B$, minimum lumen diameter; arrow $\mathrm{C}$, Ao side) and the length (arrow $\mathrm{D}$ ) of the arterial duct on the main pulmonary arteriogram

四徵（TOF）, DORV などが挙げられる. 以後 HLHS におけるDSに関して述べる。 BT shuntから右室肺 動脈（RV-PA）conduitを用いた Norwood 手術が主 流となり，その成績はここ 20 年間に劇的に改善し た ${ }^{12-15)}$. しかし低体重児, 右室機能低下, 重度 TR, IAS，染色体異常などの危険因子がある場合の死亡率 は 20〜 50\% と高く, 両方向性 Glenn（BDG）までの interstage の死亡もある ${ }^{16,17)}$. これらの high risk群 では高侵襲な Norwood 手術を回避して, First palliation としてより低侵襲な両側肺動脈絞扼（Bil-PAB） とDSを施行して, 発育後にNorwood \& BDG 手術 を施行することで生存率が上昇した ${ }^{16-18)}$.

DS は hybrid room でBil-PAB と同時に hybrid ア プローチで主肺動脈にシースを挿入して留置する方 法と後にカテーテル室で FV から経静脈的に留置す る方法がある. ステントは self expandable と balloon expandableのものがある. 経静脈的に留置する場合 は合併症を起こさずに手技を遂行するための配慮が必 要である.

\section{HLHS における経静脈的 stent 留置手技}

HLHS では Bil-PAB 後であってもカテーテルなど を RV から下行大動脈（DAo）まで進めると RV のス 
トレッチ，PR・TRの出現などから血圧が低下しやす いので，極力 RV をストレッチさせない materials を 使用する。人工呼吸管理下の施行が安全だが, 鎮静剂 等の使用から血管拡張による血圧低下がある場合は昇 圧剂を併用して血圧を高めに保つように心掛ける。

1. $4 \mathrm{~F}$ end-hole Berman catheter などで主肺動脈造影 を行い, $\mathrm{AD}$ を描出し, その径(肺動脈側, 再狹 部, 大動脈側）と全長を計測する（Fig. 14）. 将来
の Norwood 手術を考慮するとAD 全長が過不足 なく覆われるDS が理想的で, stent 径は migration を避けるために参照血管径+1〜2 mm のものを選 択する.

2. 通常の stent 留置方法（back loading 法；Fig. 15） ガイドワイヤーは AD の形状に合致するように逆 U 時状に整形して用いる. Long sheathをDAoま

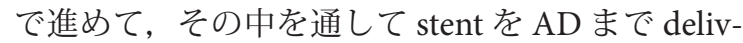

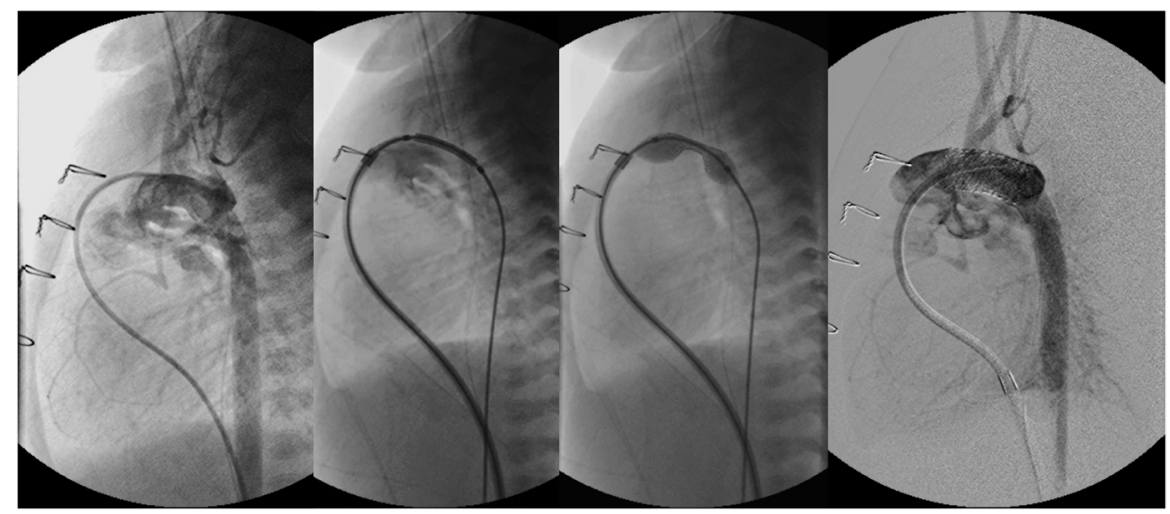

Fig. 15 Usual method of stent implantation using the back-loading technique Wire: 0.035" Hanako; Long sheath: 6F Brite tip; Stent: Express ${ }^{\mathrm{TM}}$ LD Vascular stent (1880).

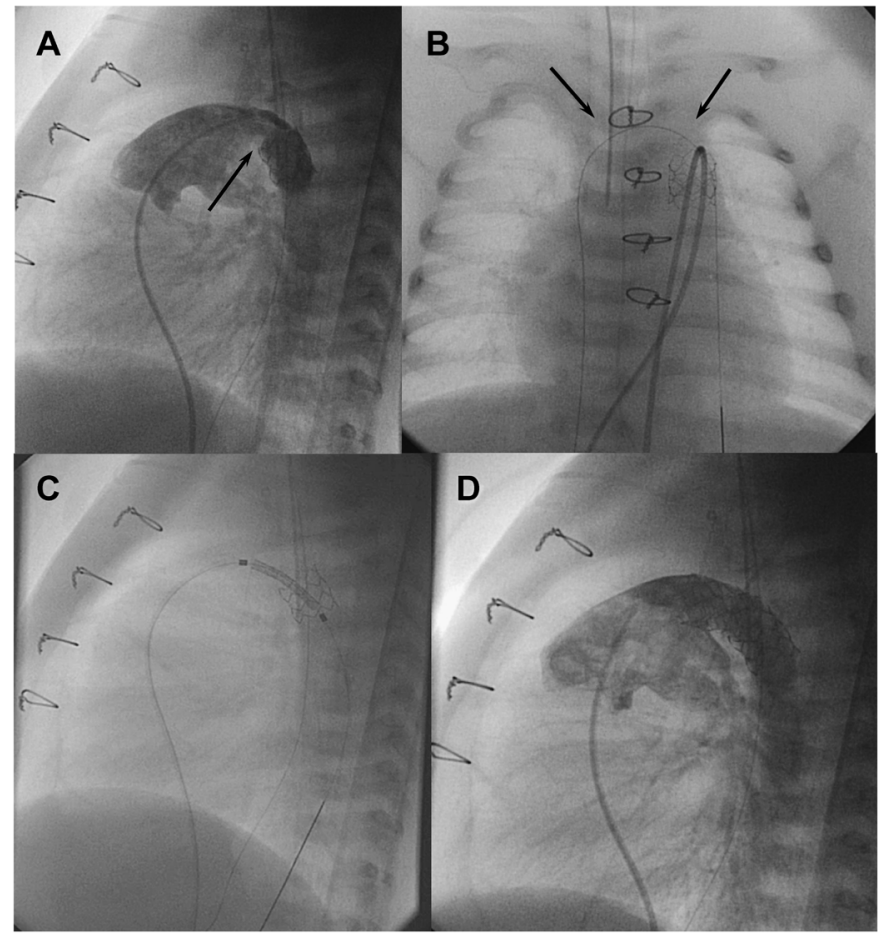

Fig. 16 Ductal stenting using the bare delivery technique

The main pulmonary arteriogram revealed the constriction of the pulmonary arterial side of the arterial duct (AD), which was not covered by the previously implanted stent ( $A$; arrow). The guide wire was formed in vitro into an inverted $U$-shape to fit the curvature of the $A D(B$, arrows). During the procedure, blood pressure was maintained at a higher level after intravenous infusion of epinephrine $(10 \mu \mathrm{g})$, and a stent $(6 \mathrm{~mm}$ in diameter and $18 \mathrm{~mm}$ in length) (Palmaz Genesis ${ }^{\oplus} 1860$ ) was delivered into the AD by bare delivery $(C)$ and implanted (D). 
Table 5 Characteristics of 12 cases receiving DS at our hospital

\begin{tabular}{lc}
\hline Age (day) & $3-107$ (median 24) \\
Weight (kg) & $2.0-3.3$ (median 2.7) \\
Underlying disaese & HLHS (6), cAS (2), \\
& unbacanced AVSD (1), \\
& IAA (2), TA TGA (1) \\
\hline Length of AD (mm) & $4.3-32.7$ (median 17.0) \\
Diametr of AD (mm) & \\
Pulmonary arterty side & $2.7-9.4$ (median 6.3) \\
Center & $1.9-7.9$ (median 3.9) \\
Ao side & $3.8-10.5$ (median 6.9) \\
Stent *before remount & \\
Size & Medium (5), Small (9) \\
Diameter (mm) & $5-10$ (median 6) \\
Length (mm) & $12-29$ (median 18) \\
Way of implantation & Common (5), Bare delivery \\
& $(6)$, Hybrid (1) \\
Stent afer implantation & \\
Diameter (mm) & $4.9-9.7$ (median 8.0) \\
Length (mm) & $9.8-18.3$ (median 15.5)
\end{tabular}

DS, ductal stenting; HLHS, hypoplastic left heart syndrome; cAS, critical aortic valve stenosis; AVSD, atrioventricular septal defect; IAA, interrupted aortic arch; TA, tricuspid atresia; TGA, transposition of the great arteries; $A D$, arterial duct.

eryする. Sheath 引いて stent を露出し, sheath から確認造影をして stent 位置を調節して, stent を留置する。

3. Bare delivery technique（Fig. 16） 血圧が低下す るために Long sheathをDAoへ運べない場合に有 用である. Long sheath は用いないか，RVまで進 めておく.ガイドワイヤーは AD の形状に合致す るように逆 U 時状に整形する (B; 矢印). stentを Bare の状態で AD まで deliveryする(C). Delivery 時に血圧が低下する場合は 10 倍希䣋エピネフリン (5〜10 $\mu \mathrm{g})$ を sheath から静注する（通常血圧は 20 30 $\mathrm{mmHg}$ 程度上昇する). 血圧が維持されて いる間に, 気管チューブや胃チューブを位置決め の対象として stentを留置する(D). AD の狭窄部 が限局している場合は stent migration が生じやす いので, 可能な限り最狹部にステント中央部が位 置するように留置する*.

\section{合併症・問題点}

2006 年 10 月から 2013 年 10 月の間に当院で 12 症 例（Table 5）に施行した DS の最中または後に生じた
Table 6 The ways to deal with problems and complications accompanied with DS in the 12 cases

\begin{tabular}{|c|c|c|}
\hline Problems/complications & $\mathrm{n}$ & How to deal with it \\
\hline $\begin{array}{l}\text { Decrease of blood pres- } \\
\text { sure during the proce- } \\
\text { dure }\end{array}$ & 7 & $\begin{array}{l}\text { Forming the guide wire } \\
\text { into an invert } U \text { shape } \\
\text { Bare stent delivery } \\
\text { Injection of epinephrin } \\
(5-10 \mu \mathrm{g})\end{array}$ \\
\hline $\begin{array}{l}\text { Ductal constricriction of } \\
\text { the part where is not } \\
\text { covered the previous } \\
\text { stent }\end{array}$ & 2 & Additional stenting \\
\hline $\begin{array}{l}\text { Fear to compress the } \\
\text { bronchus because of } \\
\text { right DAo and a long } \\
\text { course of the AD }\end{array}$ & 1 & $\begin{array}{l}\text { Covering only the nar- } \\
\text { row part of pulmonary } \\
\text { artery side in the } A D \\
\text { Alternative way: use of } \\
\text { selfexpandable stent }\end{array}$ \\
\hline Dissection of DAo & 1 & Additional stenting \\
\hline Development of CoA & 1 & Norwood procedure \\
\hline $\begin{array}{l}\text { Need for the catheter to } \\
\text { turn in the LV to deli- } \\
\text { very }\end{array}$ & 1 & Delivery from FA \\
\hline
\end{tabular}

DS, ductal stenting; DAo, descending aorta; CoA, Coarctation of the Aorta; LV, left ventricle; FA, femoral artery.

合併症・問題点を Table 6 に示す．最多の問題は手技 中の血圧低下であり, 12 症例中 7 症例に認められ, その内の 5 症例は HLHS であった. 特に大動脈弁閉 鎖では血圧低下から冠血流が低下して重篤な心機能 低下をきたし得るので, Bare stent delivery やエピネ フリン静注などの対応を施して手技に臨む必要があ る.

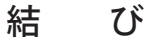

ロープロファイルなマテリアルが開発され，新生児 においても様々なカテーテル治療が施行されるように なった． 新生児のカテーテル治療は外科治療よりも低 侵襲で施行できることが最大の利点であるが，外科治 療と同様に重篤な合併症が起こりえ，また術者の違い が成績に反映される手技である．新生児のカテーテル 治療を行う場合は，合併症とその対応策を熟知した上 で，合併症が起きてからではなく，起こらないように 配慮しながら手技を遂行することが最も大切である.

*電子版にて動画を配信している. 


\section{引用文献}

1) Rashkind WJ, Miller WW: Creation of an atrial septal defect without thoracotomy. A palliative approach to complete transposition of the great arteries. JAMA 1966; 196: 991-992

2) Park SC, Neches WH, Zuberbuhler JR, et al: Clinical use of blade atrial septostomy. Circulation 1978; 58: 600-606

3) Park SC, Neches WH, Mullins CE, et al: Blade atrial septostomy: Collaborative study. Circulation 1982; 66: 258-266

4) Shrivastava S, Radhakrishnan S, Dev V, et al: Balloon dilatation of atrial septum in complete transposition of great artery-A new technique. Indian Heart J 1987; 39: 298-300

5) Thanopoulos BD, Georgakopoulos D, Tsaousis GS, et al: Percutaneous balloon dilatation of the atrial septum: Immediate and midterm results. Heart 1996; 76: 502-506

6) Ali Khan MA, Mullins CE, Bash SE, et al: Transseptal left heart catheterisation in infants, children, and young adults. Cathet Cardiovasc Diagn 1989; 17: 198-201

7) Atz AM, Feinstein JA, Jonas RA, et al: Preoperative management of pulmonary venous hypertension in hypoplastic left heart syndrome with restrictive atrial septal defect. Am J Cardiol 1999; 83: 1224-1228

8) Justino H, Benson LN, Nykanen DG: Transcatheter creation of an atrial septal defect using radiofrequency perforation. Catheter Cardiovasc Interv 2001; 54: 83-87

9) Danon S, Levi DS, Alejos JC, et al: Reliable atrial septostomy by stenting of the atrial septum. Catheter Cardiovasc Interv 2005; 66: 408-413

10) Bacha EA, Daves S, Hardin J, et al: Single-ventricle palliation for high-risk neonates: The emergence of an alter- native hybrid stage I strategy. J Thorac Cardiovasc Surg 2006; 131: 163-171

11) Alwi M: Management algorithm in pulmonary atresia with intact ventricular septum. Catheter Cardiovasc Interv 2006; 67: 679-686

12) Sano $\mathrm{S}$, Ishino $\mathrm{K}$, Kado $\mathrm{H}$, et al: Outcome of right ventricle-to-pulmonary artery shunt in first-stage palliation of hypoplastic left heart syndrome: A multi-institutional study. Ann Thorac Surg 2004; 78: 1951-1957, discussion, 1957-1958

13) Ashburn DA, McCrindle BW, Tchervenkov CI, et al: Outcomes after the Norwood operation in neonates with critical aortic stenosis or aortic valve atresia. J Thorac Cardiovasc Surg 2003; 125: 1070-1082

14) Gaynor JW, Mahle WT, Cohen MI, et al: Risk factors for mortality after the Norwood procedure. Eur J Cardiothorac Surg 2002; 22: 82-89

15) Stasik CN, Gelehrter S, Goldberg CS, et al: Current outcomes and risk factors for the Norwood procedure. J Thorac Cardiovasc Surg 2006; 131: 412-417

16) Galantowicz M, Cheatham JP: Lessons learned from the development of a new hybrid strategy for the management of hypoplastic left heart syndrome. Pediatr Cardiol 2005; 26: 190-199

17) Akintuerk H, Michel-Behnke I, Valeske K, et al: Stenting of the arterial duct and banding of the pulmonary arteries: Basis for combined Norwood stage I and II repair in hypoplastic left heart. Circulation 2002; 105: 1099-1103

18) Bacha EA, Daves S, Hardin J, et al: Single-ventricle palliation for high-risk neonates: The emergence of an alternative hybrid stage I strategy. J Thorac Cardiovasc Surg 2006; 131: 163-171 